\title{
Politics of Locating Muslim Women in Islamic Discursive Tradition in India
}

\section{Esita Sur ${ }^{\dagger}$}

\section{Abstract}

In postcolonial India, narratives about Muslim women have revolved around tropes, such as tin talaq (divorce), purdah (veil), polygamy and Islam. These have always played a significant role to shape their homogenised identity: an existence of oppression and subordination. However, the paper will try to argue that the marginalisation of Muslim women is not only structural but also discursive (popular as well as religious), which produce them as 'victims' and 'voiceless others'. The paper will also try to argue that Muslim women have already been discursively produced as incapable of progressive thinking, and waging struggle against their subordination. Therefore, the paper shall make an attempt to examine the impact of popular as well as Islamic discourses in shaping the identity of Muslim women in India, and locate those alternative spaces, where Muslim women can challenge their homogenised existence as a category as well as dominant discourses on their victimhood.

Key words: Discourse, Resistance, Subjugated Discourse, Stereotypes and Exclusion

\footnotetext{
${ }^{\dagger}$ Assistant Professor in Political Science, Scottish Church College, Kolkata, Email: esita_sur@yahoo.com esitasur@rediffmail.com

(C)2015 Sur. This is an Open Access article distributed under the terms of the Creative Commons Attribution License (http://creativecommons.org/licenses/by/2.0), which permits unrestricted use, distribution, and reproduction in any medium, provided the original work is properly cited.
} 


\section{Introduction}

Discourses do not automatically cause social inequalities but that they are both indicative of the position of any group within a given society and provide a justificatory context in which inequities can arise, persist, and even be made to seem normal (Sarkar, 2008: 199). Dominant discourses locate identities of Muslim women ${ }^{1}$ in their victimhood and passivity. However, it is equally important to locate those discourses, which construct and stereotype their identity, as discourses and stereotypes are linked to social exclusions. The discourses, as dictated by Foucault (1980), are not saintly innocent vegetarians but implicated with power and institutions, based on epistemological violence and institutional hierarchies. These discourses fiercely compete with each other for occupying and, hegemonising our realms of knowledge, spheres of morality and ways of thinking (Basu, 2010: 77-80). Discourse, as defined by Foucault (1980), refers to: ways of constituting knowledge, together with the social practices, forms of subjectivity and power relations, which are inherent in such knowledge and relations between them. Discourses are more than ways of thinking and producing meaning. They constitute the 'nature' of the body, unconscious and conscious mind and emotional life of the subjects they seek to govern (Weedon, 1987: 108). It is also a form of power that circulates in the social field, and can attach to strategies of domination as well as those of resistance.

Dominant discourses, which portray Muslim women in India as 'passive victims' or 'voiceless others' always dominate alternative discourses, which tend to portray them as empowered and capable of making their decisions (Shaban,

\footnotetext{
${ }^{1}$ Muslim women in India should not be considered as a homogenous entity. Differences in their experiences are shaped by their location in class, region and family as well. Educational attainment and opportunities or lack of it, are also important indicators to mould their experiences. Therefore, the issue of heterogeneity needs to be mentioned. However, for the theoretical requirement, I am addressing the identity question of Muslim women by considering them as a unitary category.
}

2012). These discourses contest tooth and nail among themselves in order to control to make us think, speak, perceive "reality" or "truth". Therefore, we can argue that identities to a large extent are discursive. The discursive identity of Muslim women as "oppressed" and subjugated prevails over those alternative discourses, which emphasise their agency and resistance to hegemonic structures of patriarchy, religion and community (Shaban, 2012).

In the Indian context, discourses on Muslim women can be divided under few heads: discourses based on Islamic tradition ${ }^{2}$ and popular discourses, which are comprised by the media, Indian state as well as national debates on Muslim issues. Therefore, the paper argues that the identity construction of Muslim women is a continuous production of discursive practices and tradition. This argument does not deny the significance of factors like socioeconomic marginalisation, discriminations, policies of the derelict Indian state in perpetuating their subordination, etc. However, it argues that Islamic discursive tradition and practices may further reinforce Muslim women's marginalisation in community as well as in society.

The paper argues in favour of delving into alternative discourses, which highlight the politics of difference and heterogeneity within the community and show that Muslim women may also develop a critique of their own marginality from their locations and perspectives. This paper will try to address a few questions: a) how the politics of

\footnotetext{
2 Talal Asad delineated the concept of Islamic Discursive Tradition. He argued that Islamic discursive tradition is always historically situated, and tied to and produced by power. It is integrally related to the production of knowledge and institutional conditions for the production of knowledge. Islam becomes an arena of many processes that become Islamic because they belong to the discursive tradition of Islam. According to Asad, the tradition consists essentially of discourses that seek to instruct practitioners regarding the correct form, and purpose of a given practice that precisely because it is established and has a history. The task of Islamic discursive tradition is to maintain orthodoxy and dominance of dominant discourses (Manger, 2013).
} 
representation through dominant discourses homogenises the community? b) apart from popular discourses, how do Islamic discursive practices affect the formation of the category of 'Muslim Women' in India? c) is there any significance of alternative discourses to disturb the homogenised category of Muslim women? In this way, the paper will make an initiative to scrutinise the formation of dominant discourses on Muslim women, and identify them as one of major reasons of their marginalisation in the mainstream. Moreover, the paper will also highlight the significance of alternative discourses as sites, which may challenge the dominant representation of Muslim women as 'powerless others'. Therefore, the paper argues that the identity of Muslim women is not only shaped by dominant discourses but also by alternative discourses, which tend to show that identity and subjectivity are not fixed rather in a state of continuous making.

\section{Methodology}

This article has followed the hermeneutical method, which would enable us to take a holistic or 'contextual' approach to the analysis of women's question in Muslim society. It is a way of clarifying the meaning of a text by interpreting it historically. This method revolves around the text, the author and the context. Therefore, hermeneutical model can help us to locate women's rights with regard to three aspects of the Quran as the text: a) the context in which the text was written and the way women's rights have been addressed; $b$ ) the grammatical composition of the text; and c) the whole text, its worldview. It may be argued that the method of Quranic interpretation on women's rights and equality is subject to specific time, history and particular circumstances. The practice of polygamy was found acceptable in ancient times due to wars and other factors. However, interpreting this practice as relevant in contemporary context may be considered as a product of patriarchal setup. A reader must understand the implications of the Quranic expressions during the time in which they were expressed in order to determine their proper meaning.
Interpretation of women's rights in Quran can be divided under two heads: reading and exegesis. At the level of a reading, every reader can interpret. The attitudes, experiences, memory and perspectives of the language of each reader shape the level of interpretation. At the level of exegesis, an attempt is made to overcome individual perspectives to approach the Quran more objectively (Wadud, 1999, 3-7). Therefore, to locate women's rights in Islam, one should exegete the Quran from a gender perspective by giving adequate respect to the particular context and time. However, the irony is that male-dominated society has never been successful to define women's rights, bypassing the gendered attitudes embedded in this hierarchical society. In the words of Asghar Ali Engineer, Islam is an egalitarian religion but it is the male-dominated society, which has taken away women's rights and there has been a requirement to revisit Islamic legal structures. The Quranic verses are divided under two heads, namely, contextual and normative. When it comes to women's rights, normative pronouncements have precedence over contextual. However, during the early centuries, contextual often had precedence over normative, and it had been quite 'normal' that time (Engineer, 2013, 27-30). Hence, these formulations became widely acceptable in that society. In modern society, women's rights have been treated as normative rather than contextual.

Here reference can be drawn to the aspect of milk-e-yamin, i.e., legitimising sexual relations with the slave girls. Jurists from all schools on Islamic Jurisprudence do agree on this but it cannot be accepted in our modern society (Engineer, 2013, 34-41). Therefore, the question of women's rights and identity has to be addressed in changing socio-political and economic context. It also shows that the discursive identity of Muslim women is not free from the politics of interpretation and misinterpretations, which are contextual and largely indigenous.

\section{Community and Marginalisation: On Politics of Representation}


Dominant discourses ${ }^{3}$ on Muslim community have represented them as homogenous community spelled with a capital C. It not only upholds the ideals of unity and common experience of marginality but has also generated stereotypes. For example, the Hindu nationalists have always levelled the community as 'terrorists', anti-nationals', 'suspicious' and Muslim males are labelled as 'husbands of four wives', and many of these stereotyping are more political creations and far away from the reality as possible (Shaban, 2012). However, the overall impact of this on the Muslim community is grave. It influences their psyche and confidence to assert their rights (Shaban, 2012, 3-7). This sort of representation overlooks the fact that Muslims are deeply divided on the lines of caste, class, language and regional locations. Even on ideological standpoints, community is divided. Moreover, this homogeneous representation seems to be problematic for Muslim women as well. At one hand, the hegemonic representation of the community as 'backward' or 'conservative' tends to fix their identity in larger society; on the other, it also overlooks internal conflicts on the women's question within the community. The conservative, progressive, as well fundamentalists groups within the community have conflicting standpoints on women's rights in Islam. In India, the yardstick of defining an Islamic group or school as conservative does not only depend on their unwillingness to accept western values but also on their rigid stand to accept women's rights, already guaranteed within the Islamic framework. Moreover, fundamentalists are those who always dodge to change their standpoint on women's rights. Several schools like, Hanafi, Maliki, Safai'i, Hanbali support men's right to triple talaq (divorce in one

\footnotetext{
${ }^{3}$ Discourse can be defined as entity, which is composed of sequences, signs and relations among objects, subjects and statements. It is the generation of the concept of the conversation within all modalities and contexts. It signifies the totality of codified language used in a given field of intellectual enquiry and of social practice. Therefore, discursive production means the production and prevalence of a particular knowledge by the dominant groups in society (Howarth, 2002: 14-24).
}

sitting), and polygamy, as these are embedded in religion. Conservative interpretations also justify wife beating, and impose several restrictions on women in the name of religion (Engineer, 1999). Moreover, their perceptions and interpretations on women's role in society are based on the rigid demarcation between men and women. On the contrary, progressiveness of an Islamic group in India cannot be defined in terms of their inclination for Western values; rather progressive groups uphold the gender-just nature of Islam, which gives them extra mileage to fight for women's rights. Progressives like late Ashgar Ali Engineer have always argued that women's rights are inherent in Islam but the patriarchal society has taken away rights from women. Progressive groups have not only relentlessly challenged the conservative interpretations but also exhorted for reinterpretations of the Quranic verses. However, in reality, progressive voices hardly are represented in larger society, and the women question is mainly handled by the conservative sections within the community. Dominant discourses hardly highlight all these internal differences and conflicts, especially on women's issues, within the community. The politics of representation should reflect the difference among women rather than identity, as it is crucial for understanding gender oppression and marginality.

The making of the category of Muslim in India has been typically influenced by popular discourses, which are characterised by prevalent trends in the larger social milieu about the conservatism and ingrained backwardness of the community. It may also be argued that Muslim women are discursively ${ }^{4}$ represented as backward, victimised, silenced and eventually invisible, and it has undergirded the construction of 'other' identity categories.

\footnotetext{
${ }^{4}$ Dominant discourses also include discourse analysis. It incorporates a wide range of linguistic and non-linguistic material-speeches, reports, manifestos, historical events, interviews, policies, ideas, even organisations and institutions - as 'texts' or 'writings' that enable the subjects to experience the world of objects, words, and practices (Howarth, 2002, 35-40).
} 
Zoya Hasan and Ritu Menon have pointed out that recent interventions on Muslim women in postcolonial India are caught up in misconceptions that usually leave Muslim women invisible. Two sets of misunderstandings seem to plague discussions of Muslim women: the tendency to see Muslims, particularly Muslim women, as a monolithic category; and the overwhelming importance attached to Islam, especially the Muslim personal law in defining Muslim women's status (Menon, 2004, 45-50). It also highlights the ways in which gender and racially defined community and class ideologies worked simultaneously to deny even middle class Muslim women the limited visibility (Sarkar, 2008: 198-200).

The marginal status of Muslim women has also closely been associated with stereotypes, entrenched by tin talaq (divorce), multiple marriages and purdah. ${ }^{5}$ Such stereotypes in both popular and academic discourses are further reinforced by the systematic scholarship and information on the unequal access to resources and opportunities experienced by different groups of women in India today (Sarkar, 2008). It is also important to highlight that the stereotyped images of the Muslim community colour the understanding about the community, and affect even the policies formulated for them. Stereotypes also cause discrimination in the labour market as well as public and private institutions (Shaban, 2012: 7 10). Moreover, it is worth mentioning that Muslim women's marginalisation is not only socio-economic but also discursive as well as political.

\section{Islamic Discursive Tradition and Muslim Women in India}

Apart from popular discourses, religious and community discursive practices play an important role to construct women's identity

\footnotetext{
5 Purdah is a religious and social practice of female seclusion prevalent among some Muslim countries. It takes two forms: physical segregation of the sexes and the requirement that women cover their bodies so as to cover their skin and conceal their form (Engineer, 2013, 173).
}

within the community. Being a minority community, religious traditions and cultural practices have remained significant, and the community has remained very protective about their practices, traditions and symbols.

In the words of Talal Asad, the Islamic discursive tradition can be understood as a "historically evolving set of discourses, embodied in practices and institutions of Islamic societies and hence deeply imbricated in the material life of those inhabiting them" (Anjum, 2006: 4). He also mentioned that the content and context of the scriptures, the historical experience of Islam in its formative years, etc., constitute the discursive tradition of Islam. However, Asad had never recognised the role of local and indigenous practices of Islam. Asad's ingenuity lies in his rethinking of the concept of tradition in order to grasp the meaning of past. His reworking of the concept of traditions: of the symbolic anthropologists who had seen tradition as emanating from autonomous religious symbols (rather than linked with social process), and of those who saw tradition in an exact opposite way: merely a ruse, a manipulative ideology, and a guise for motivations and factors whose true provenance lies in political and economic realm. According to Asad, both views misconstrue the nature of tradition, and overlooked the possibilities opened up by the past that is embodied in a tradition. Asad sees the basic functions of traditions as establishing orthodoxy in a given historical and material context. In his words, "[a] tradition consists essentially of discourses that seek to instruct" (Anjum, 2006: 3). He also mentioned that orthodoxy is a relationship of power, and the question remains how it comes to be established as one set of doctrines and no other. However, Asad said that anthropologist must not concede to multiple "Islams". Asad's task remains unfinished until the apparent tension between a single Islamic discursive tradition and multiple local orthodoxies is theorised.

Now the puzzle derived from the above discussion is - can we imagine Muslim women's rights and identity in India by 
overlooking "multiple interpretations", which are made of indigenous political, socioeconomic contexts, local practices, etc.? Muslim women in India are not only the citizens of the Indian state but also the member of the largest minority community, which is socioeconomically a backward community. Culturally, this community has presented itself as a self-legislating and self-governing community, which exhibits their absolute control over their religion and the private domain. The Indian State has never tried to intervene in these domains in order to maintain and respect the minority identity and culture. These contexts have profound impact on Muslim women's rights and identity. The political and religious leadership within the community have always remained protective and conservative about Muslim women's rights. Therefore, the result has been obvious: the great tradition of Islam has always emphasised the principles of egalitarianism and gender justice but the multiple interpretations (read: misinterpretations) which are embedded in our indigenous political, communal and socioeconomic contexts and practices have produced a homogenised discourse, which portrays Muslim women as "oppressed" and "victims" in our society (Engineer, 1999). The verses on talaq (divorce), polygamy, and wife beating have been interpreted in such a manner that has never been compatible with the humanist notion of women's rights in Islam in India. As late Asghar Ali Engineer forcefully argued that Islam had given all rights to women but this male-dominated and patriarchal society had taken away their rights (Engineer, 1999: 25-30). Interpretations and misinterpretations had never been freed from the patriarchal-influences and bypassed the alternative discourses, which highlight Muslim women's agency to negotiate with hegemonic patriarchal structures. Therefore, Islamic discursive tradition and practices have played a great role to shape their identity.

\section{Muslim Women and Islamic Discursive Tradition on Personal Laws in India}

In India, the discursive identity of Muslim women has always revolved around the tropes of personal laws, triple talaq and purdah (veiling). All these tropes have produced them as a homogenous as well as political category. National debates on the Shah Bano case, Imrana ${ }^{6}$ and Gudiya ${ }^{7}$ cases have not only reified their victimhood but also raised the need for Muslim personal law reform to protect women's rights in Islam. The issue of personal law reform is not a new issue in Islamic societies. Many countries like Egypt, Malaysia had opted for Muslim personal law reform to ensure gender justice. However, in India, the issue of Muslim personal law reform through Uniform Civil Code $^{8}$ has remained extremely

${ }^{6}$ In 2005, a 70-year-old father-in-law raped a young girl named Imrana in a remote village of Uttar Pradesh. Religious leaders and the caste panchayat issued the fatwa that she had to get married to her father-in-law, and consider her husband as her son. The Women's Commission and the State could not do anything on the ground that it was an internal affair of the community.

7 Gudiya's case came into media focus in August when Mohammad Arif, who had gone missing in action since the 1999 Kargil war, was repatriated by Pakistan as a Prisoner of War. During the five-year absence of Arif, who was presumed dead after initially being declared a deserter, Gudiya had married Taufiq and carried his child. After his marriage, Arif had spent a very short time with Gudiya, as he was called for service during the Kargil conflict. On his return to his native village, Arif found his wife Gudiya married to Taufiq. However, the village council reunited Arif and Gudiya following a decision. Taufiq, who hails from Pataudi village in Gurgaon, tried to get Gudiya back but the council ruled in favour of Arif and, she had since then been living with him (Kumar, 2006: 1).

${ }^{8}$ Uniform Civil Code in India is the debate to replace the personal laws based on the scriptures and customs of each major religious community in the country with a common set governing every citizen. These laws are distinguished from public law and cover marriage, divorce, inheritance, adoption and maintenance. Article 44 of the Directive Principles of State Policy set its implementation as duty of the State. Apart from being an important issue regarding secularism in India, and it became one of the most controversial topics in contemporary politics during the Shah Bano case in 1985. The debate then focused on the Muslim Personal Law, which is partially based on the Sharia law and remains 
sensitive to the community. It is perhaps due to the reason that discourses on personal laws are religious, and based on their minority identity. Any reform in personal laws has been perceived as a threat to Islamic tradition and practices. That is why: Foucault correctly pointed out that in every society, the production of discourse is at once controlled, selected, organised and redistributed according to a certain number of producers, whose aim is to sustain its power, and dominant discourses are always effective, organising and regulating relations of power, as it is a regime of truth (Basu, 2010: 69).

In India, the religious authority within the community has always controlled discourses on personal laws. The way religious authority (Moulavis and Ulemas) constructs the knowledge about women's rights in Islam, makes it inevitable that a dominant discourse has the power to interpret major social, political and economic issues and events. Dominant discourses, as implicated with power and institutions, silence the other side of truth, rationality and universality. Dominant knowledge, as produced by the religious leadership, completely overlooks the necessity of ljtehad (rational and creative interpretation of the Quran) to address women's rights. The progressive section within the community has always raised their voice for the creative reinterpretation of women's rights in India. However, progressive discourses are always dominated by conservative discourses.

Therefore, the socio-political and cultural meanings of triple talaq, purdah (veiling) and polygamy have never been from the patriarchal influence, which have always accorded Muslim women a subordinate position in society. Muslim women's identity has to be perceived through these socio-political and cultural practices, as mediated through discourses and the effects of power (Basu, 2010: 76).

The question of Muslim women's identity cannot be understood without the references to two trends of Islamic discursive tradition. In

unreformed since 1937, permitting unilateral divorce and polygamy in the country(Hasan, 2000).
India, we not only have a great tradition of Islam but also "little traditions" of Islam (Anjum, 2006: 3). It means that there have been differences between Islam as a core religion and as "lived Islam". In our society, lives of Muslim women revolve around this "lived Islam". Islamic discursive tradition in India remains incomplete without the light thrown upon the relationship between tradition and orthodoxy. In India, the religious leadership has remained over-possessive about the rights of Muslim women in India. Misogynist interpretations of the Quran, different types of fatwas exhibit that religious orthodoxies not only show a power hierarchy but also give rise to "little traditions", which are products of our own time, space and context.

The impact of discursive traditions is best manifested through the politics of interpretations of the text. In Islam, the art of interpretation of the religious text remains central because it does not only control the production of knowledge on Islamic way of life and women's rights but also denies women to access the religious knowledge and, which ultimately affects their identity. The production of religious knowledge is backed by patriarchal power politics as well as the male worldview. That is why the principle of gender equality as ensured in Islam, has never been materialised in reality, as interpretations of rights of Muslim women have revolved around patriarchal power politics and, the difference between conservative and progressive standpoints on crucial issues like divorce, polygamy, etc.

Several schools like the Jafari, the Hanafi, the Maliki, the Safai'i, the Hanbali support men's right to triple talaq (talaq in one sitting), and polygamy as these are, for them, embedded in religion. The Quran emphasises that divorce should not be a hasty impulsive act but should also be finalised only after a period of waiting during which the couple is counselled and, given a chance to rethink on the decision. Talaq is a procedure that can be initiated by the husband alone without the consent of his wife. Besides, the exercise of talaq is extra-judicial and in no way subject to external check. 
Technically, therefore, the power of the husband to divorce is absolute. Talaq may be pronounced in a number of ways, e.g., (1) Ahsan (2) Hasan (3) Bid' ah. The Ahsan form of talaq is Talaq-I-Sunna. The repudiation does not take place at a single sitting nor can it take place during menstruation. Iddat is observed during the period following menstruation that is tuhr or the purity period. Two arbitrators from both sides are appointed to bring about reconciliation. During the iddah period the marriage is not dissolved. If reconciliation takes place, the marriage is saved and no nikah is needed. In Ahsan talaq even after the third pronouncement of talaq, after the 'iddah's period, the marriage is revocable. The man can remarry his divorced wife. This practice is in accordance with the teaching of the Quran and according to Sunna rules. ${ }^{10}$ Both Sunni and Shia schools approve of talaq-a-ahsan. The Hasan form is talaq-a-sunna but is not as commonly accepted as talaq-a-ahsan. The man is supposed to pronounce talaq during the successive periods of purity or tuhr. A couple can live together as husband and wife if the husband so desires before he pronounces the third talaq. On the third talaq, the marriage is

\footnotetext{
9 Iddat has been defined as the waiting period for a widow or divorced. In Shariat terminology, it is the waiting period for a woman when her nikah with a man is no more valid for one reason or the other. The waiting period means that after the cessation of nikah the woman has to restrain herself for another nikah until the prescribed period of three months is over (Engineer, 1999: 12-15).

10 Muslims in India are divided into two major sects, Sunni and Shia. Sunni Muslims regard themselves as the orthodox and traditionalist branch of Islam. The word Sunni comes from "Ahl al-Sunna", the people of the tradition. The tradition in this case refers to practices based on precedent or reports of the actions of the Prophet Muhammad and those close to him. Sunnis venerate all the Prophets mentioned in the Qoran, but particularly Muhammad as the final Prophet. Shiites, in contrast, believe that only the heirs of the fourth caliph, Ali, are the legitimate successors of Mohammed. All subsequent Muslim leaders are seen as temporal figures. Each sect has many different schools or sub-sects. Sunnis are divided in four sects: the Hanafi, the Malaki, the Shafai, and the Hanbali. Indian Shias are are divided into three sub-sects: the Ithna-Asharis, the Ismailis and Zaidis (Engineer, 1999: 20-25).
}

dissolved and the talaq is irrevocable. Therefore, he cannot remarry her. If she wants to remarry, she has to perform Halala, i.e., marry another man, consummate the marriage, consequently dissolve it, and only then remarry her divorced husband. Prophets and Caliph Ali condemn this process of Halala. All Shia and Sunni schools of thought have approved of Talaq-a-Hasan. Since it is not irrevocable, it is not very popular; yet, the Hanbali Sunni School gives it more importance than to other types of talaq. Talaq-a-Bidah is a form of divorce, which is severely criticised since it goes against the rules laid down by the Quran. However, the Sunna approves it. In this form of talaq the husband unilaterally, without the consent or knowledge of the wife, pronounces talaq. Husband can pronounce Talaq once or three times simultaneously, without paying attention to the fact whether wife is in a state of thur. The Prophet did clearly not approve of this form of divorce (Baxamusa, 1994: 110-112). Even the provisions relating to the polygamy and veiling in the holy Quran have been misinterpreted for several times. It is true that marriages up to four are valid but conditions of equal love and, justice were also stipulated in the Quran with a context. It was precisely meant for orphans and war widows to provide them security through marriage. Noted Pakistani commentator Maulana Muhammad Ali said that verse 4:3 permits polygamy under circumstances; it does not enjoin it, nor even permit it unconditionally (Engineer, 1999: 118122). Therefore, it is quite clear that in order to uphold the traditional values of maledominated society, the real spirit of the Quran and its deep concern with justice are totally overlooked by the art of misinterpretation and misappropriation of the religion. In this way, little traditions influence women's lived experiences.

\section{State and Political Leadership: Constructing Muslim Women as 'Other'}

The whole discussion will remain incomplete, if the role of the Indian State is not elaborated in reinforcing dominant discourses on personal laws. In a country like India, where the Muslim 
community is the largest minority, protection of Islamic discursive tradition remains the most important duty for the Indian State. The Indian State for many times has ended up with a judgment call where: the dominant discourse on Muslim women's rights to a large extent prevailed over the alternative sets of knowledge, which derives its inspirations from a more egalitarian and gender-based understanding of Islam. The Indian State has remained confused regarding: which discourse to endorse: Dominant or Subjugated: Liberal or Communitarian: Muslim women as citizens of the Indian state or the wards of community?

Muslim women in India do not only suffer due to her location in the marginalised community but also from the dubious treatment of the state. This pro-community attitude has forced the state to overlook many structures of discriminations embedded in the intra-group relations, and it ultimately portrays Muslim women as the 'other' in the vocabulary of the Indian political system. This was visible in Shah Bano Case (1986). ${ }^{11}$ While all other Indian women may claim the legal right to spousal support after divorce, Muslim women may not. While other women criminally prosecute their husbands for bigamy, Muslim women may not. According to the Sharia Act, a divorced Muslim woman is entitled to a reasonable and fair provision of maintenance within the period of Iddat; two years of maintenance for her

\footnotetext{
${ }^{11}$ According to Shariat Act (1937), Muslim women cannot demand lifelong maintenance after talaq. It is generally supported on the ground of minority community identity, religion and culture. In 1986, when Shah Bano went to the Supreme Court for demanding her lifelong maintenance, it gave rise to a clash between the collective rights of the community and individual rights and identity. The Supreme Court gave its verdict in favour of Shah Bano. However, Muslim fundamentalists protested this move vehemently on the ground that any change in Shariat Act by the State is against the identity of Muslim community. So the Shah Bano case (1986) shows that women's claim to equal rights is treated as a betrayal to community, the culture and the religion. In addition, the Indian state very consciously institutionalises gender inequality in personal laws on the ground of minority identity and culture (Hasan, 2000: 283-287).
}

children; mehr ${ }^{12}$ and all the properties should be given to her by her relatives and husband's relatives. If she does not get it at the time of divorce then she can apply to the Magistrate to direct her husband to follow the order. In response to this, Shah Bano, (a 65-year-old woman) filed a case against her husband and the Supreme Court granted her appeal for lifelong maintenance from her husband. Nevertheless, this judgement was not a simple one; it opened the floodgates of debates and discussions on the tricky relationship between gender, community and the state. In response to the Shah Bano case and the subsequent legislation, Muslim community leaders split broadly into two camps. Conservative leaders considered the judgment as an attack to Muslim identity as well as Muslim personal law. Progressive leaders felt that the Supreme Court judgement was in accordance with the basic tenets of Islam and thus it was not an intrusion in Muslim personal law (Hasan, 2000: 279-285).

Although progressive leaders did not agree with everything the judgment said, they supported the substantive conclusion: that Muslim man should provide adequate maintenance for destitute, divorced women beyond the period of Iddat. Constitutional scholar Granville Austin (2004) has argued that the conservative opposition was not only imbued with ideological factors but also with economic and political factors. The judgement was not only an attack to Muslim identity but also to the economic interests of Muslim men who might otherwise be faced with maintenance payment to ex-wives. Additionally, the political interests of the conservative Muslim leadership were threatened as well. If personal laws were codified, the religious leaders would lose their power to interpret the Quran. To soothe ruffled

\footnotetext{
12 In Islam, mahr is a mandatory payment, in the form of money or possessions paid by the groom, or by groom's father, to the bride at the time of marriage that legally becomes her property. While the mahr is often money, it can also be anything agreed upon by the bride such as jewellery, home goods, furniture, a dwelling or some land. Mahr is typically specified in the marriage contract signed during an Islamic marriage (Engineer, 2013: 180181).
} 
feelings, the Rajiv Gandhi Government enacted the Muslim Women (Protection of Rights on Divorce) Bill, 1986. This bill explicitly excluded Muslim women from the right to maintenance available under the $\mathrm{CrPC}^{13}$ (Hasan, 2000: 265269).

The promise of formal equality to all and ensuring rights to Muslim women is in juxtaposition, especially when Indian State surrenders to the conservative standpoint of women's rights, bypassing minority progressive views. By accepting the conservative position, the state itself constructs the identity of Muslim community as conservative and reluctant to change. However, the Indian State has its own logic. The conservatives as well as fundamentalists can label any sort of intervention to reform Muslim personal law in favour of women as an intrusion in minority community. Therefore, protecting minority identity and culture becomes the major concern for the state and in order to do so the women's question remains neglected and conferred to the hands of the community leaders. It also proves that laws are immensely patriarchal in nature and influenced by the male worldviews. Rather than acting as agents of social change, laws reinforce male domination against women (Mackinnon, 1989: 5-6). In fact, the protectionist role of the state not only reinforces the minority community identity of Muslim women but also marginalises from the mainstream.

\section{Alternative Discourses on Muslim Women's Agency and Resistance}

Therefore, dominant discourses on Muslim women have always presented their quintessential images. These dominant forms

\footnotetext{
13 The Code of Criminal Procedure $(\mathrm{CrPC})$ is the main legislation on procedure for administration of substantive criminal law in India.It was enacted in 1973 and came into force on 1 April 1974. It provides the machinery for the investigation of crime, apprehension of suspected criminals, collection of evidence, determination of guilt or innocence of the accused person and the determination of punishment of the guilty. Additionally, it also deals with public nuisance, prevention of offences and maintenance of wife, child and parents (Hasan, 2000).
}

of knowledge within a society are always determined in and through power relations, which are an effect of knowledge production. Moreover, the category of Muslim women is produced within discourses with special reference to the discursive formation of a particular period and culture.

Above discussions show that how some discourses have shaped, and created meaning systems that have gained the status and currency of 'truth', and dominate how we define and organise both our social world, and ourselves whilst other discourses are marginalised and subjugated, yet potentially 'offer' sites where hegemonic practices can be contested, challenged and 'resisted'. In Foucault's view, there is no fixed and definitive structuring of either social (or personal) identity or practices, as there is in a socially determined view in which the subject is completely socialised. Rather, both the formation of identities and practices are related to, or are a function of historically specific discourses. An understanding of how these and other discursive constructions are formed may open the way for change and contestation. Thus, there are both discourses (dominant and alternative) that constrain the production of knowledge, dissent and difference and some that enable 'new' knowledge and difference(s). The questions that arise within this framework, are to do with how some discourses maintain their authority, how some 'voices' get heard whilst others are silenced, who benefits and how - that is, questions addressing issues of power/empowerment/disempowerment (Foucault, 1980: 80-90).

Dominant representations of the Muslim women through stereotypes like parda, talaq, polygamy not only reinforce a certain mode of knowledge about their identity but also tend to overlook the role of difference in their experiences based on class, education, family background as well as regional location in shaping their identities. This, not only stereotypes also bypass the question of resistance and agency of Muslim women and, shape their identity as coherent and 
homogeneous within popular discourses in India. However, it is not only "fixed identity and subjectivity" but identification with the community and social structures, which provides multiple dimensions to their existence. It is also important to mention that discourses are enmeshed in power, and there are no power relations without resistance. Moreover, Foucault has elaborated the fact that every resistance is mediated, informed, produced, and becomes meaningful through discourses and power (Foucault, 1980: 72).

It helps us to understand that the continuous mediation and negotiation with the patriarchal structures by Muslim women. It becomes meaningful within the discursive framework of the marginalised and subjugated. It also creates an alternative space to locate their identity, scope to conceptualise the notion of dynamic and multi-layered subjectivities of Muslim women in varying contexts. It is important to highlight that the oppressor/oppressed model of gender relations, as produced by the western scholarship has always portrayed Muslim women for decades as passive and submissive beings, shackled by structures of patriarchy. As institutionalised and hegemonic maledomination through patriarchal institutions and practices have not only bypassed women's agency and resistance but also projected women's identity as essentialised entity. Moreover, such a model remains encumbered by the binary terms of domination and subordination, and is also insufficiently attentive to motivations, desires and goals, which are not necessarily captured by these binary terms. It is an imperative to take the initiative to restore the absent voice of women to analyses of subjectivities of Muslim women, and present Muslim women as active agents, who live an existence far more complex and richer than past narratives have suggested. In the words of Saba Mahmood, agency should not only be defined "as a synonym for resistance to the relations of dominations but as a capacity for action that historically specific relations of subornation enable and create" (Mahmood, 2004: 12).
As experiences of Muslim women are mediated through the discourses of Islam, religious patriarchy and community, a meaningful and collective resistance is possible through a common discursive sharing. This marginalised and subjugated framework has always highlighted the notion of alternative space in which Muslim women have relentlessly tried to negotiate with hegemonic structures in society. It has also raised debates between material basis for social action versus a common discursive sharing as a possible strategic ground for any socially meaningful and politically relevant collective action, such as resistance. Therefore, the purpose of the marginalised discourse is to challenge the dominant one, which is centred on a firm belief in the absolute, authentic and unquestionable meaning. Muslim women's resistance and collective action against the hegemonic patriarchal structures show that a critique can also be developed through these alternative discourses.

\section{Role of Muslim Women as Collective Agents}

The marginalised discourses not only challenge the dominant one but also the liberal as well as poststructuralist notion of fully autonomous self, which conceives agency as the property of individuals rather than individuals as members of groups or socially interconnected networks of cause and effect. However, it is important to recognise that individual sufferings and transgressive practices are also largely ineffective, when it comes to challenging systems of oppression. Unless women understand themselves as members of groups, they will fail to see the pattern of oppression, and fail to understand that group resistance is important to challenge structural oppression (Bowden \& Mummery, 2012).

Muslim women from several corners of India have organised and voiced themselves for their rights. The Shah Bano case of the 1980s was a landmark in the discourse on "Muslim women's rights" in India. At that time, however, few Muslim women actually participated in the debates, which were shaped by either male religious leaders or politicians or by 'secular' 
women's groups and it had scant Muslim representation. Since the 1980s, several Muslim-women led organisations have emerged in urban areas across the country, some of which have formed networks to advocate for Muslim women's rights. These networks have different but overlapping ideological bases, priorities and strategies. They aim to challenge the authority of the Muslim religious leadership, represented by institutions such as the All India Muslim Personal Law Board. Today these groups are also challenging the dominant conception of Muslim women as a passive, homogenous group with a common set of interests. Not only this, these groups like the MWRN (Muslim Women Rights Network) and the BMMA demonstrate new forms of political agency and are creating a space for a conceptualisation of identities that complicates the dichotomy between religious and genderbased interests and aims to reconcile the two in a manner that protects and promotes women's rights without denying the importance of religious identity (Kirmani, 2009: 5-10).

It signifies that they are not only the passive victims of their community but can also develop a critique of their own marginalisation by themselves. Several instances are there to substantiate this argument. In Tamilnadu, Daud Sharifa Khanam has taken an initiative to build a separate mosque for women with the claim that women have equal right to pray and worship. Not only this, her organisation STEPS has also delineated the concept of women's jamaat to pose a challenge to the patriarchal nature of men's jamaat. Women's jamaat has emerged as a space where women can raise their voice against violence and oppression (Khanam, 2004: 18-25). In Lucknow (Uttar Pradesh), Shaista Amber has constituted All India Muslim Women Personal Law Board to challenge the male-dominated and patriarchal nature of All India Muslim Personal Law Board (Amber, 2011). The AIMPLB eventually released its own copy of the model nikahnama in 2005, which was most probably the result of both the initiative of its own members as well as external pressure from women's groups. However, most women's groups met this with scorn because they felt it did not outline sufficient protections for women and particularly, it does not include a provision for women to have the right to divorce their husbands and neither does it discourage the practice of polygamy.

All these instances indicate women not only symbolise the plight of the community but also provide a critique of their own marginalisation and have their own ways to define gender equality within Islamic framework. The emergence of these groups in several parts of India highlights the fact that women are not only being vocal to the rigid and gender biased interpretations of the Quran but they are being conscious about that fact that rights are given and equality is ensured in the religion. Therefore, these initiatives not only ask for reinterpretation of religious texts to ensure gender justice but also create alternative discourse on Muslim women's rights in India.

\section{Conclusion}

From the above discussion, it is quite clear that a powerful instrument for maintaining the marginalisation of Muslim women in postcolonial India was their invisibility in intellectual as well as public discourses. These discourses showed that the goals and objectives of gender equity and justice require continuous efforts to address and reduce sources of distress, exclusions, vulnerabilities and silences of Muslim women. Above discussion also shows that the identity of Muslim women is not only the part of dominant discourses but also of alternative discourses. The locus of power, operating behind these discourses to shape our identities needs to be addressed in future ventures.

\section{References}

Anjum, O. (2006, July 6). Islam as a Discursive Tradition: Talal Asad and his Interlocutors.

Retrieved 1 October 2014, from www.academia.edu.

Asad, T. (1986). The Idea of an Anthropology of Islam. Washington DC: Center for Contemporary Arab Studies. 
Amber, S. (2011, September). All India Muslim Women Law Board. Retrieved 9 December 2013, from

www.muslimwomenpersonallaws.com.

Austin, G. (2004). Working A Democratic Constitution: A History of the Indian Experience. New Delhi: Oxford University Press.

Baxamusa, R. (1994). Need for Change in the Muslim Personal Law Relating to Divorce in India.

Basu, P. (2010). Post Modernism, Marxism, Postcolonialism. Kolkata: Avenel Press.

Bowden, P., \& J. Mummery (2012).

Understanding Feminism. New Delhi: Rawat Publications.

De, R. (2013, 21 August). Personal Laws: A Reality Check. Frontline

Engineer, A. A. (2013). Islam, Women and Gender Justice. New Delhi: Gyan Publishing House.

Engineer, A. A. (1999). The Quran, Women and Modern Society. New Delhi: Sterling Publishers Private Limited.

Engineer, I. (2012). 'Political Leadership, Mobilisation and Violence', in A. Shaban, (ed.) Lives of Muslims in India: Politics, Exclusion and Violence, New Delhi: Routledge.

Foucault, M. (1980). Power/ Knowledge: Selected Interviews and Other Writings - 197277, trans. Gordon et al. New York: Pantheon Books.

Howarth, D. (2002). Discourse. New Delhi: Viva Books Private Limited.

Hasan, Z. (2000), Politics and the State in India, New Delhi: Oxford University Press.

Khanam, S. (2004, August 21). Women's Mosque Planned. Retrieved 9 December 2013, from www.stepswomensjamat.com.
Kirmani, N. (2009). Claiming Their Space: Muslim Women-led Networks and Women's Movement in India, International Journal of Women's Studies, Volume 9.

Kumar, A. (2006, 3rd January). Gudiya Dies. Retrieved 8 October 2014, from www.thehindu.com.

Mahmood, S. (2004). Politics of Piety: The Islamic Revival and the Feminist Subject. Princeton: Princeton University Press

Mackinnon, C. A (1989), Toward a Feminist Theory of the State. Harvard: Harvard University Press.

Menon, H. Z. (2004). Unequal Citizens: A Study of Muslim Women in India. New Delhi: Oxford University Press.

Manger, L. (2013). Muslim Diversity: Local Islam in Local Contexts. Routledge: London.

Naheed, U. (2009, 11 July), Muslim Women in India Are in Miserable Condition. Retrieved 10 December 2013, from www.islamicterrorism.wordpress.com.

Shaban, A. (2012). Introduction. In A. Shaban (ed.), Lives of Muslims in India (pp. 17-20), New Delhi: Routledge.

Sarkar, M. (2008). Visible Histories Disappearing Women: Producing Muslim Womanhood in Late Colonial Bengal. New Delhi: Kali for Women.

Wadud, A. (1999), Quran and Woman: Reading the Sacred Text from a Woman's Perspective. New Delhi: Oxdord University Press.

Weedon, J. (1987). Discourses on Several Subjects. Gale ECCO Print Editions.

\section{Acknowledgements}

I kindly convey my regards to the anonymous referees for their insightful as well as thoughtful comments. I am thankful to them for their time, knowledge and expertise. 